\title{
AKURASI PREDIKSI DURASI PENYELESAIAN PROYEK DENGAN EARN VALUE MANAGEMENT DAN EARN SCHEDULE (STUDI KASUS PROYEK BANGUNAN GEDUNG DI UNESA)
}

\author{
Gde Agus Yudha Prawira Adistana', Purwo Mahardi², Mochamad Firmansyah Sofianto ${ }^{3}$, \\ Dian Eksana Wbowo 4 \\ 1,2,3 Jurusan Teknik Sipil, Fakultas Teknik, Universitas Negeri Surabaya \\ ${ }^{4}$ Jurusan Pendidikan Teknik Sipil dan Perencanaan, Fakultas Teknik, Universitas Negeri Yogyakarta, \\ Email: gdeadistana@unesa.ac.id
}

\begin{abstract}
The earn value method (EVM) has been widely recognized and proven to provide an overview of the performance of construction project implementation from the aspects of time and schedule. Specifically EVM is used to evaluate the progress of the work, so identification of deviations both on time and cost can be done early. The Earn Schedule (ES) method is an elaboration to the schedule analysis on the EVM method. This study aimed to examine and compare the capability of the two methods, namely the earn value and earn schedule methods in predicting the completion time of construction project. The research used the real data from the Unesa building project. The results showed that at week 9, the value of CPI was 1.15 or had a variant cost of $13.32 \%$ lower than the planned budget. While for the schedule aspect, both methods indicated a delay in the project with the delay variant of $0.16 \%$. The ES method is able to give information of how long the delay in time unit of 0.02 week.
\end{abstract}

Keywords: accuration, actual cost, earn value, earn schedule, planed value

\begin{abstract}
ABSTRAK
Metode nilai hasil (EVM) telah dikenal luas dan terbukti mampu memberikan gambaran kinerja pelaksanaan proyek konstruksi dari aspek waktu dan jadwal. Secara khusus EVM digunakan untuk mengevaluasi progress pekerjaan sehingga dapat dilakukan identifikasi lebih awal terhadap penyimpangan baik terhadap waktu maupun biaya. Metode Earn Schedule (ES) merupakan pendalaman terhadap analisis jadwal pada metode EVM. Penelitian ini dilakukan untuk menguji dan membandingkan kemampuan dua metode yaitu metode earn value dan earn schedule dalam memprediksi waktu penyelesaian proyek konstruksi. Data penelitian menggunakan data pelaksanaan dari pembangunan proyek bangunan gedung di Unesa. Hasil penelitianmenunjukkan bahwa pada minggu ke-9, nilai CPI adalah sebesar 1,15 atau memiliki varian biaya sebesar 13,32\% lebih rendah dari anggaran yang direncanakan. Sedangkan dari aspek jadwal, kedua metode mengindikasikan bahwa terjadi keterlambatan pada proyek yaitu dengan varian keterlambatan sebesar 0,16\%. Metode ES mampu memberikan informasi berapa lama keterlambatan yang terjadi dalam satuan waktu yaitu sebesar 0,02 minggu.
\end{abstract}

Kata Kunci: akurasi, biaya aktual, nilai hasil, earn schedule, biaya rencana 


\section{PENDAHULUAN}

Kesuksesan sebuah proyek dapat ditinjau dari tercapainya sasaran yang ditetapkan yaitu selesai tepat waktu, tepat biaya dan memenuhi spesifikasi mutu yang disyaratkan. Dalam rangka menjamin tercapainya ketiga sasaran itu, maka pelaksanaan proyek memerlukan sebuah sistem pengendalian yang baik. Sistem pengendalian proyek dapat berupa sebuah metode yang didesain, dikembangkan secara sistematis dan terorganisir dengan baik. Agar sebuah sistem pengendalian proyek dapat berfungsi dengan efektif maka diperlukan pencatatan dan pelaporan semua informasi di lapangan secara kontinyu.

Salah satu informasi yang penting untuk diketahui adalah bagaimana peningkatan penggunaan biaya terhadap anggaran atau terhadap waktu. Selain itu, dengan mempertimbangkan bahwa perubahanperubahan merupakan sesuatu yang sering terjadi dalam pelaksanaan sebuah proyek konstruksi, maka diperlukan sebuah metode yang lebih terintegrasi untuk dapat menggambarkan bagaimana kemajuan atau progres pelaksanaan di lapangan (Czemplik, 2014).

Metode nilai hasil (EVM) merupakan salah satu metode pengendalian yang mengukur secara kuantitatif kinerja dan kemajuan dari proyek (PMI, 2011; GAO, 2012). EVM dikembangkan mulai tahun 1960, namun publikasi mengenai penggunaannya pada bidang manajemen rekayasa, pengadaan dan proyek konstruksi mulai meluas sejak EVM diperkenalkan kembali di tahun 1976 oleh Departemen Pertahanan Amerika serikat (Moselhi, 2011). EVM digunakan untuk menganalisis proyek berdasarkan status dan trend dari proyek pada saat monitoring dilakukan. Dari beberapa referensi literatur menyatakan bahwa tujuan EVM adalah untuk menyediakan informasi yang mencukupi dalam menentukan hal-hal berikut ini: (1) apa yang telah dicapai dari pekerjaan yang direncanakan, (2) biaya yang dikeluarkan untuk pekerjaan yang telah selesai, (3) apakah biaya pekerjaan yang diselesaikan lebih atau kurang dari yang direncanakan, (4) apakah proyek mengikuti rencana (APM, 2006).
Analisis EVM dapat memberikan gambaran mengenai kondisi proyek dari aspek biaya maupun jadwal. Dari segi biaya dengan menggunakan EVM, dapat diketahui apakah biaya yang digunakan sesuai dengan rencana anggaragan atau sebaliknya mengalami pembengkakan biaya. Sedangkan dari segi jadwal dapat diperoleh informasi apakah pelaksanaan proyek sesuai dengan waktu rencana atau sebaliknya mengalami keterlambatan (Czarnigowska, 2011). Informasi mengenai kondisi proyek ini sangat penting karena diperlukan oleh pengelola proyek untuk membuat keputusan yang tepat dan mengambil tindakan pembetulan apabila terjadi penyimpangan dari rencana yang dibuat sebelumnya.

Secara teknis EVM menggunakan progres pekerjaan sebagai indikasi apa yang akan terjadi pada proyek di waktu mendatang (Bhosekar, 2012). Elemen utama dalam analisis EVM adalah biaya, yang artinya bahwa untuk mengukur baik itu kinerja biaya maupun kinerja jadwal, keduanya berbasis biaya. Menurut Moselhi dengan menggunakan metode EVM, akurasi keberhasilannya dalam memprediksi penggunaan biaya sampai tahap penyelesaian proyek adalah cukup baik. Namun, hasil yang berbeda didapat bila EVM digunakan untuk memprediksi durasi, akurasi prediksinya kurang memuaskan (Moselhi, 2011). Menurut Lipke, kurang berhasilnya EVM dalam meramalkan waktu penyelesaian proyek karena EVM mengukur kinerja penjadwalan tidak dalam parameter waktu namun lebih ke parameter biaya (Lipke, 2012). Valley sependapat dengan Lipke dimana pada EVM indikasi kinerja penjadwalan tidak ditunjukkan dengan parameter waktu tetapi masih terkait dengan biaya dan nilai hasil yang dinyatakan dengan unit biaya (Valley etc, 2004).

Pada tahun 2003, Lipke mengembangkan sebuah metode yang merupakan perpanjangan dari EVM. Metode ini selanjutnya dikenal sebagai earn Schedule (ES) yang dikembangkan untuk dapat melakukan analisis penjadwalan dengan lebih baik. Berbeda dengan EVM, ES mendemonstrasikan kemungkinan untuk menjelaskan kinerja biaya dengan unit waktu. Dengan kata lain, ES memfasilitasi analisis berbasis waktu dari sebuah penjadwalan sehingga lebih mudah 
dipahami dibandingkan dengan EVM (Lipke, 2014). Setelah ES pertama kali diperkenalkan, setahun kemudian Henderson mengembangkan ES untuk dapat digunakan memprediksi durasi penyelesaian proyek. Ada dua persamaan yang dikembangkan Henderson untuk memprediksi durasi penyelesaian proyek Salah satu persamaan tersebut akan digunakan dalam penelitian ini (Henderson, 2004; 2007).

Lew Hecht melakukan penelitian untuk menguji keampuhan ES dalam melakukan peramalan pada proyek angkatan laut AS. Hasil penelitian lew Hecht menunjukkan bahwa ES berhasil dalam menjelaskan kinerja penjawalan dalam variabel waktu (Hecht, 2007-2008). Pengujian lainnya terhadap kemampuan dari ES dilakukan oleh tim peneliti Vanhoucke dan Vandevoorde yang menerapkan simulasi untuk menilai kinerja EVM dan ES dalam meramal durasi penyelesaian proyek. Hasil pengujian dari tim ini menunjukkan bahwa ES mengungguli metode-metode lain yang digunakan untuk memprediksi waktu penyelesaian proyek (Vanhoucke dan Vandevoorde, 2007). Meskipun beberapa penelitian termasuk di dalamnya simulasi dari tim Vanhoucke dan Vandevoorde mengindikasikan nilai yang positif terhadap kinerja ES, namun perlu dilakukan pengujian lebih lanjut dengan menggunakan data real dan kondisi proyek yang berbeda. Penelitian ini mencoba menguji keampuhan kedua metode yaitu ES dan EVM dengan menggunakan data real sebuah proyek konstruksi sebagai sebuah studi kasus.

\section{Konsep Dasar Metode EVM}

EVM merupakan sebuah metode yang didesain untuk mengintegrasikan antara waktu dan biaya.

Menurut ulasan yang ditulis oleh Rojo (2014), ada tiga konsep dasar yang dimiliki oleh EVM, antara lain: (1) semua tahapan pekerjaan pada proyek "mendapatkan" nilai hasil apabila pekerjaan tersebut telah selesai dikerjakan, (2) Nilai hasil/Earned Value (EV) kemudian dapat dibandingkan dengan biaya aktual dan biaya yang direncanakan untuk menentukan kinerja proyek dan memprediksi tren kinerja masa depan, (3) Kemajuan fisik diukur dalam satuan moneter (rupiah), sehingga kinerja jadwal dan kinerja biaya dapat dianalisis dengan persyaratan yang sama.Ketiga konsep tersebut adalah penjelasan untuk tiga data utama pada metode EVM.
Adapun data utama yang diperlukan untuk melakukan analisis dengan metode EVM antara lain:

1. BCWS: Budgeted Cost of Work Scheduled dikenal juga sebagai PV: Planned Value

2. BCWP: Budgeted Cost of Work Performed dikenal juga sebagai EV: Earned Value

3. ACWP: Actual Cost of Work Performed dikenal juga sebagai AC: Actual Cost

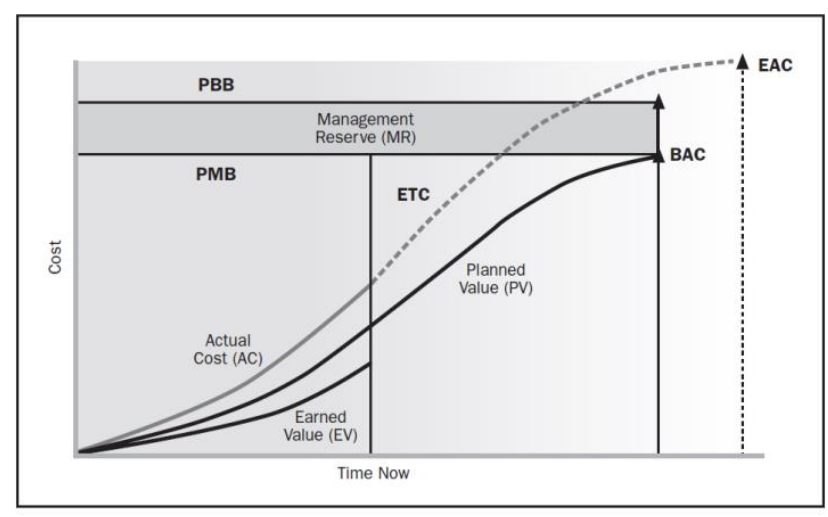

Gambar 1 Parameter-parameter EVM Sumber: PMI (2011)

Keefektifan dan efisiensi kinerja analisis EVM ditentukan oleh nilai ambang batas yang dinyatakan dalam prosentase untuk mewakili indeks kinerjanya (Pico, 2013). Ambang batas yang relevan dalam EVM antara lain varian biaya/cost variance (CV) dan varian waktu/schedule variance (SV).

Tabel 1. Kinerja jadwal dan biaya dari CV dan SV

\begin{tabular}{llll} 
Variance & $(-)$ & $\mathbf{0}$ & $\mathbf{( + )}$ \\
\hline CV & $\begin{array}{l}\text { Pembengkakan } \\
\text { biaya }\end{array}$ & $\begin{array}{l}\text { Tepat } \\
\text { biaya }\end{array}$ & $\begin{array}{l}\text { Penghematan } \\
\text { biaya }\end{array}$ \\
\hline SV & Terlambat & $\begin{array}{l}\text { Tepat } \\
\text { waktu }\end{array}$ & $\begin{array}{l}\text { Mendahului } \\
\text { jadwal }\end{array}$
\end{tabular}

Sumber: Kim (2010)

Nilai variansi pada EVM baik variansi biaya maupun jadwal diperoleh dari:

$$
\begin{aligned}
& C V=E V-A C . \\
& S V=E V-P V .
\end{aligned}
$$


Sedangkan nilai indeks biaya dan indek jadwal diperoleh dari:

$$
\begin{aligned}
& \mathrm{CPI}=\mathrm{EV} / \mathrm{AC} \\
& \mathrm{SPI}=\mathrm{EV} / \mathrm{PV}
\end{aligned}
$$

\section{Kelemahan EVM}

CV dan CPI (persamaan 1 dan 3) dapat menjadi indikator biaya dengan baik, namun tidak dengan SV dan SPI (persamaan 2 dan 4) yang tidak cukup jelas untuk mendeskripsikan status jadwal. Sebagai contoh, apabila terjadi sebuah skenario dimana pada akhir periode laporan ditemukan bahwa beberapa aktivitas non-kritis mendahului dari progress rencana, sedangkan beberapa aktivitas kritis mengalami keterlambatan, kondisi ini dapat menghasilkan nilai $\mathrm{SPI}=1$, Apabila hanya melihat nilai SPI yang dihasilkan maka seolah-olah proyek sesuai dengan jadwal perencanaan, padahal kondisi sebenarnya dapat sama sekali berbeda. Fenomena ini diperkuat oleh penjelasan dari (Vandevoorde and Vanhoucke, 2006) yang menyatakan bahwa indikator kinerja waktu dengan SV maupun SPI pada metode EVM memiliki beberapa kelemahan antara lain: (1) SV diukur dalam satuan moneter dan tidak dalam satuan waktu, yang membuatnya sulit dipahami dan oleh karena itu sering menjadi sumber salah tafsir, (2) SV =0 (atau SPI = 1) bisa berarti bahwa sebuah tugas selesai, tapi bisa juga berarti bahwa tugas tersebut berjalan sesuai rencana. (3) menjelang akhir proyek, SV selalu menuju ke nilai sama dengan 0 yang menunjukkan kinerja sempurna bahkan jika proyeknya terlambat. Demikian pula, SPI selalu menuju ke nilai sama dengan 1 menjelang akhir proyek, menunjukkan efisiensi jadwal 100\% bahkan dalam proyek ini sudah terlambat.

\section{Konsep Dasar ES}

Untuk mengatasi anomali nilai kinerja indikator waktu yang diperoleh, maka Lipke (2014) memperkenalkan konsep jadwal yang berbasis waktu (ES). Dalam metode ini, nilai yang diperoleh pada titik monitor tertentu ditelusuri ke depan atau ke belakang ke baseline kinerja ( $S$ curve) atau PV. Titik persimpangan ini dipindahkan ke bawah pada sumbu X (skala waktu) untuk menghitung jadwal yang diterima ES (lihat Gambar 2). Oleh karena itu, ES ditemukan dengan mengidentifikasi di mana kenaikan PV terjadi pada EV. Ini menerjemahkan EV ke dalam peningkatan waktu dan mengukur kinerja proyek sebenarnya dibandingkan dengan kinerja waktu yang diharapkan. Adapun parameter parameter jadwal yang dipakai adalah:

$$
\begin{aligned}
& S V_{(t)}=E S-A T \\
& S P I_{(t)}=E S / A T
\end{aligned}
$$

dimana AT adalah mengacu pada waktu aktual. Berbeda dengan SV, SV (t) dinyatakan dalam satuan waktu, sehingga lebih mudah untuk ditafsirkan. Nilai SV $(\mathrm{t})<0$ adalah menunjukkan lamanya unit waktu yang tertinggal dari perencanaan jadwal proyek atau merupakan kinerja yang tidak diharapkannya (Vandevoorde and Vanhoucke, 2006).

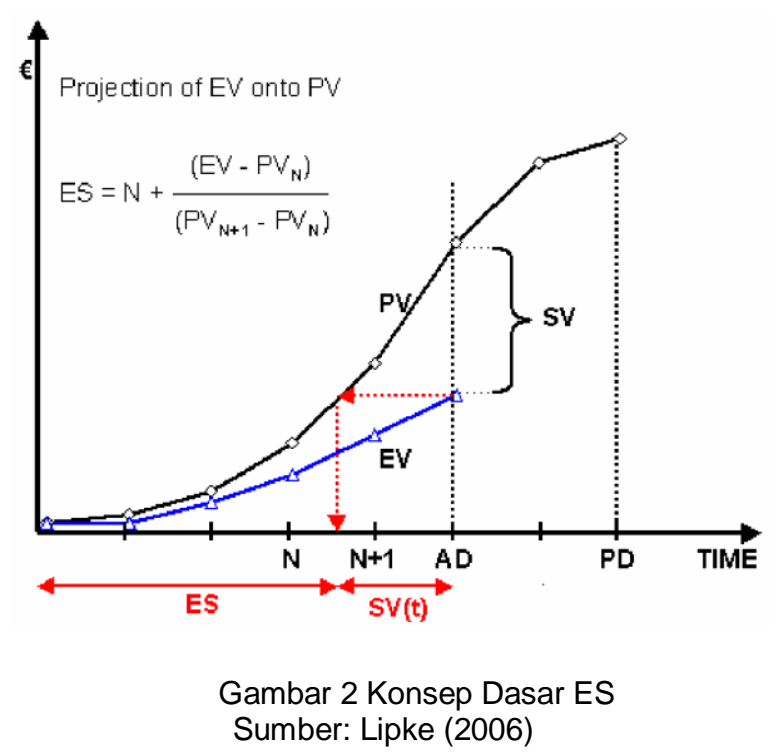

Perilaku SV (t) dari waktu ke waktu menghasilkan SV terakhir (t) yang sama persis dengan waktu sebenarnya saat selesai (sementara SV selalu berakhir pada nol). Hal yang sama berlaku untuk indikator SPI (t), yang memiliki nilai akhir yang mencerminkan kinerja jadwal proyek akhir (sementara SPI selalu sama dengan 1).

\section{METODE}

Dalam rangka untuk mengetahui kinerja proyek dari segi biaya dan waktu serta mengetahui tingkat akurasi dalam memprediksi kinerja waktu pada khususnya, maka pada penelitian ini diambil sebagai sebuah studi kasus yaitu proyek pembangunan gedung di Universitas Negeri Surabaya (Unesa). Proyek pembangunan gedung yang dimulai di tahun 2017 ini berlokasi di daerah Kampus Lidah Wetan. Durasi penyelesaian proyek berdasarkan kontrak adalah selama 5 bulan. Meskipun hanya memiliki lingkup pekerjaan 3 
lantai, namun karena memiliki fungsionalitas ruang yang beraneka ragam serta kapasitas daya tampung pengguna yang cukup besar yang didesain untuk mengakomodasi semua kegiatan akademik maupun non-akademik civitas Unesa, sehingga proyek ini merupakan paket pekerjaan konstruksi yang cukup kompleks dan memiliki volume pekerjaan yang besar khususnya pekerjaan struktur beton.

Evaluasi proyek terhadap kinerja biaya maupun jadwal dilakukan pada pertengahan waktu pelaksanaan yaitu pada minggu ke 9 .

\section{Analisis berdasarkan EVM}

Prosedur dalam melakukan analisis dengan EVM adalah sebagai berikut:

1. Mengidentifikasi dan menghitung data-data: BAC, AC, EV dan PV.

2. Menghitung nilai Varians yaitu dengan persamaan 1 untuk varian biaya dan persamaan 2 untuk varian jadwal.

3. Menghitung indikator kinerja proyek dengan persamaan 3 untuk indikator kinerja biaya dan persamaan 4 untuk indikator kinerja waktu.

4. Menghitung indek biaya waktu yaitu $\mathrm{SCl}$ $=\mathrm{CPI}{ }^{*} \mathrm{SPI}$

5. Menghitung parameter-parameter prediksi:

To-Complete Performance Index

$\mathrm{TCPI}=(\mathrm{BAC}-\mathrm{EV}) /(\mathrm{BAC}-\mathrm{AC})$

Independent Estimate at Completion

$\mathrm{IEAC}=\mathrm{AC}+\mathrm{ETC}$

Estimate to complete

$\mathrm{ETC}=(\mathrm{BAC}-\mathrm{EV}) / \mathrm{PF}$

Variance At Completion

$\mathrm{VAC}=\mathrm{BAC}-\mathrm{IEAC}$

Independent Estimate at Completion(t) $\mathrm{IEAC}_{(\mathrm{t})}=(\mathrm{BAC} / \mathrm{SPI}) /(\mathrm{BAC} /$ bulan $)$

\section{Analisis berdasarkan ES}

Prosedur dalam melakukan analisis dengan ES adalah sebagai berikut:

1. Mengidentifikasi dan menghitung datadata: EV, PV, AT, CPI dan PD.

2. Menghitung Element Basic

$\mathrm{ES}=\mathrm{C}+\mathrm{I}$

$$
\mathrm{I}=\left(\mathrm{EV}-\mathrm{PV} \mathrm{V}_{\mathrm{c}}\right) /\left(\mathrm{PV}_{\mathrm{c}+1}-\mathrm{PV}_{\mathrm{c}}\right)
$$

3. Menghitung nilai Varians yaitu dengan

$$
S V_{(t)}=E S-A T
$$

4. Menghitung indikator kinerja waktu dan indeks biaya waktu proyek

$S P I_{(t)}=E S / A T$

$\mathrm{SCl}_{(\mathrm{t})}=\mathrm{SPI}_{(\mathrm{t})}{ }^{*} \mathrm{CPI}$

5. Menghitung parameter-parameter prediksi

$\mathrm{TSPI}_{(\mathrm{t})}=(\mathrm{PD}-\mathrm{ES}) /(\mathrm{PD}-\mathrm{AT})$

$I E A C_{(t)}=A T+(P D-E S) / P F_{(t)}$

$\mathrm{ETC}_{(\mathrm{t})}=\mathrm{IEAC}_{(\mathrm{t})}-\mathrm{AT}$ 
HASIL DAN PEMBAHASAN

\begin{tabular}{|c|c|c|c|c|c|c|c|c|c|c|c|c|c|c|c|c|c|c|c|c|c|c|c|c|c|c|c|}
\hline \multirow{4}{*}{ No } & \multirow{4}{*}{\multicolumn{2}{|c|}{ URAIAN PEKERJAAN }} & \multirow{4}{*}{$\begin{array}{c}\text { BIAYA } \\
\text { Rp } \\
\end{array}$} & \multirow{4}{*}{\begin{tabular}{|c|} 
вовот \\
$\%$ \\
\end{tabular}} & \multicolumn{21}{|c|}{ TAHUN 2017} & \multirow{4}{*}{\multicolumn{2}{|c|}{ KETERANGAN }} \\
\hline & & & & & \multirow{3}{*}{\begin{tabular}{|c|} 
M-1 \\
$07-$ Agst \\
13 -Agst
\end{tabular}} & \multirow{2}{*}{\begin{tabular}{|c|} 
M-2 \\
14-Agst
\end{tabular}} & \multirow{2}{*}{\begin{tabular}{|c|}
$\mathrm{M}-3$ \\
$21-$ Agst
\end{tabular}} & \multirow{2}{*}{\begin{tabular}{|c|} 
M-4 \\
$28-$ Agst
\end{tabular}} & \multirow{2}{*}{$\frac{M-5}{04-S e p t}$} & \multirow{2}{*}{\begin{tabular}{|c|} 
M-6 \\
$11-$ Sept
\end{tabular}} & \multirow{2}{*}{\begin{tabular}{|c|} 
M-7 \\
$18-$ Sept \\
\end{tabular}} & \multirow{2}{*}{\begin{tabular}{|c|} 
M-8 \\
$25-$ Sept \\
\end{tabular}} & \multirow{2}{*}{\begin{tabular}{|c|} 
M-9 \\
$02-0 \mathrm{kt}$ \\
\end{tabular}} & $\mathrm{M}-10$ & M-11 & $M-12$ & $\mathrm{M}-13$ & M-14 & $M-15$ & $M-16$ & $M-17$ & $M-18$ & M-19 & $M-20$ & $\mathrm{M}-21$ & & \\
\hline & & & & & & & & & & & & & & \begin{tabular}{|l|}
$09-0 \mathrm{kt}$ \\
\end{tabular} & $\mid 16-0 \mathrm{kt}$ & 23-0kt & $30-0 \mathrm{kt}$ & 06-Nov & 13-Nov & $20-\mathrm{Nov}$ & 27-Nov & 04-Des & 11-Des & \begin{tabular}{|l|l|l|} 
18-Des 2 \\
\end{tabular} & 25-Des & & \\
\hline & & & & & & 20-Agst & 27-Agst C & |03-Sept & 10-Sept 1 & 17-Sept: & 24-Sept & $01-0 \mathrm{kt}$ & 08-0kt & 15-0kt & $22-0 \mathrm{kt}$ & $29-0 \mathrm{kt}$ & 05-Nov & 12-Nov & 19-Nov & 26-Nov & 03-Des & 10-Des & 17-Des & 24-Des: & 31-Des & & \\
\hline & & & & & & & & & & & & & & & & & & & & & & & & & & & \\
\hline & & & & & & & & & & & & & & $-P$ & V & $-A$ & C & $\triangle-E$ & V & & & & & & & & \\
\hline & & & & & & & & & & & & & & & & & & & & & & & & & - & & $100 \%$ \\
\hline I & PEKERJAAN S & STRUKTUR & & & & & & & & & & & & & & & & & & & & & & 2 & & & \\
\hline & I & PEKERJAAN PERSIAPAN & 9.420 .426 .718 & $22,21 \%$ & $3.00 \%$ & $3,15 \%$ & $3.14 \%$ & $3.14 \%$ & $0.80 \%$ & $0,80 \%$ & $0.80 \%$ & $0.80 \%$ & $0.80 \%$ & $0.80 \%$ & $0.80 \%$ & \begin{tabular}{|l|}
$0.80 \%$ \\
\end{tabular} & $0,80 \%$ & $0.80 \%$ & \begin{tabular}{|l|}
$0.80 \%$ \\
\end{tabular} & $0.80 \%$ & $0.02 \%$ & $0.02 \%$ & $0.02 \%$ & \begin{tabular}{|l|l|}
$0.02 \%$ \\
\end{tabular} & $0.02 \%$ & & \\
\hline & & & 8.212 .294 .421 & $19,36 \%$ & $4,28 \%$ & $4.06 \%$ & $2.64 \%$ & $2,86 \%$ & $1.72 \%$ & $2.48 \%$ & $1.23 \%$ & $0 \%$ & $0,09 \%$ & & & & & & & & $Z$ & & & & & & \\
\hline & & & \begin{tabular}{|c|}
9.317 .281 .831 \\
\end{tabular} & $21,97 \%$ & $4.61 \%$ & $4,39 \%$ & $2.97 \%$ & $3,19 \%$ & $2.05 \%$ & $2.81 \%$ & $1.84 \%$ & $0 \%$ & $0.11 \%$ & & & & & & & & & & & & & & \\
\hline & II & PEKERJAAN STRUKTUR & & & & & & & & & & & & & & & & & & 7 & & & & & & & \\
\hline & II.1 & LANTAI 1 & \begin{tabular}{|l|}
25.489 .337 .057 \\
\end{tabular} & $60,10 \%$ & & & & $3.32 \%$ & $5.44 \%$ & $5.44 \%$ & $5.46 \%$ & $5.50 \%$ & $2.52 \%$ & $3.96 \%$ & $6.21 \%$ & $5.72 \%$ & $4.26 \%$ & $5,12 \%$ & $4,6 \%$ & $1.98 \%$ & $1.01 \%$ & & & & & & $75 \%$ \\
\hline & & & 8.006 .952 .492 & $18,88 \%$ & & $0.30 \%$ & \begin{tabular}{|l|}
$0.05 \%$ \\
\end{tabular} & $2.27 \%$ & \begin{tabular}{|l|}
$3.64 \%$ \\
\end{tabular} & $2.44 \%$ & $1.55 \%$ & $5.60 \%$ & $3.03 \%$ & & & & & & & & & & & & & & \\
\hline & & & 9.393 .618 .232 & $22,15 \%$ & & \begin{tabular}{|l|l|}
$0.77 \%$ \\
\end{tabular} & $0.05 \%$ & $2.74 \%$ & $4.11 \%$ & $2.91 \%$ & $2.02 \%$ & $6.07 \%$ & $3.48 \%$ & & & & & $Z$ & & & & & & & & & \\
\hline & II.2 & LANTAI 2 & 6.874.959.361 & $16,21 \%$ & & & & & & & & & & & & & $Z$ & $0,54 \%$ & $1,16 \%$ & $2,81 \%$ & $4,41 \%$ & $3,13 \%$ & $2.21 \%$ & $1.95 \%$ & & & \\
\hline & & & & $\mathbf{0 \%}$ & & & & & & & & & & & & & & & & & & & & & & & \\
\hline & & & & $0 \%$ & & & & & & & & & & & & 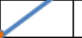 & & & & & & & & & & & \\
\hline & II.3 & LANTAI 3 & 400.514 .780 & \begin{tabular}{|l|}
$0,94 \%$ \\
\end{tabular} & & & & & & & & & & & $\angle$ & & & & & & & & & $0.47 \%$ & $0.47 \%$ & & \\
\hline & -1 & & & $0 \%$ & & & & & & & & & & & 7 & & & & & & & & & & & & \\
\hline & & & & $0 \%$ & & & & & & & & & & 7 & & & & & & & & & & . & 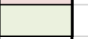 & & $50 \%$ \\
\hline & II.4 & PEKERJAAN PLAZA & 133.131 .600 & $0,31 \%$ & & & & & & & & $0.16 \%$ & $8.16 \%$ & & & & & & & & & & & & & & \\
\hline & & & \begin{tabular}{|c|}
89.812 .800 \\
\end{tabular} & 0,21\% & & & & & $0,15 \%$ & $0.00 \%$ & $0.00 \%$ & $0,0 \% \%$ & $0,03 \%$ & & & & & & & & & & & & & & \\
\hline & & & \begin{tabular}{|l|l}
101.781 .868 \\
\end{tabular} & $0,24 \%$ & & & & & $0.16 \%$ & \begin{tabular}{|l|}
$0.00 \%$ \\
\end{tabular} & 0.0007 & $0.04 \%$ & $0.04 \%$ & & & & & & & & & & & & & & \\
\hline & II.5 & PEKERJAAN RAMP & 70.910 .301 & $\begin{array}{ll}0,17 \% \\
\end{array}$ & & & & & & & 1 & 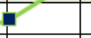 & & & & & & & & & & & & $0.09 \%$ & $0.09 \%$ & & \\
\hline & & & & & & & & & & & & & & & & & & & & & & & & & & & \\
\hline & & & & & & & & & & & & & & & & & & & & & & & & & & & $25 \%$ \\
\hline & & & & & & & & & & & & & & & & & & & & & & & & & & & \\
\hline & & & & & & & & & & & & & & & & & & & & & & & & & & & \\
\hline & & & & & & & & & & & & & & & & & & & & & & & & & & & \\
\hline II & PEKERJAAN M & MEKANIKAL, & 19.831 .840 & $0,047 \%$ & & $\mathbb{Z}$ & & & & & & & & & & & & & & $0.00 \%$ & $0.01 \%$ & $0.01 \%$ & $0.01 \%$ & $0.01 \%$ & $0.03 \%$ & & \\
\hline & ELEKTRIKAL & DAN & & & $Z$ & & & & & & & & & & & & & & & & & & & & & & $0 \%$ \\
\hline & PLUMBING & & & & & & & & & & & & & & & & & & & & & & & & & & \\
\hline & & & & & & & & & & & & & & & & & & & & & & & & & & & \\
\hline & & & & & & & & & & & & & & & & & & & & & & & & & & & \\
\hline & RENCANA & A PROGRES MingGUAN & 42.409.111.657 & $100 \%$ & $3.00 \%$ & $3,15 \%$ & $3.14 \%$ & $6.46 \%$ & $6.24 \%$ & $6.24 \%$ & $6,26 \%$ & $6.46 \%$ & $3.48 \%$ & $4.76 \%$ & $7.01 \%$ & $6.52 \%$ & $5,06 \%$ & $6,46 \%$ & $6,12 \%$ & $5,59 \%$ & $5.45 \%$ & $3.16 \%$ & $2,24 \%$ & $2,54 \%$ & $0.61 \%$ & & \\
\hline & KOMULATIF P & PROGRESS MINGGUAN & & - & $3,00 \%$ & $6,15 \%$ & $9.29 \%$ & $15.75 \%$ & $21,99 \%$ & $28.23 \%$ & $34.49 \%$ & $40,95 \%$ & $44,43 \%$ & $49.19 \%: 5$ & $56.20 \%$ & $62.72 \%$ & $67.78 \%$ & $74.24 \%$ & $80.36 \%$ & $85.95 \% \mathrm{~g}$ & $91,40 \%$ & $94.56 \%$ & $96.80 \%$ & 99.34\% & $100 \%$ & & \\
\hline & & TOTAL PENGELUARAN & 16.309 .059 .713 & $38,45 \%$ & $4.28 \%$ & $4.36 \%$ & $2.69 \%$ & $5.13 \%$ & $5.51 \%$ & $4.92 \%$ & $2.78 \%$ & $5.63 \%$ & $3,15 \%$ & & & & & & & & & & & & & & \\
\hline & & MULATIF PENGELUARAN & & - & $4.28 \%$ & $8.64 \%$ & $11,33 \%$ & $16.46 \%$ & $21,97 \%$ & $26,89 \%$ & $29.67 \%$ & $35,30 \%$ & $38,45 \%$ & & & & & & & & & & & & & & \\
\hline & & TOTAL NILAI HASIL & 18.812 .681 .931 & $44,36 \%$ & \begin{tabular}{|l|}
$4.61 \%$ \\
\end{tabular} & $5.16 \%$ & $3.02 \%$ & $5,93 \%$ & $6.32 \%$ & $5.72 \%$ & $3.86 \%$ & $6,11 \%$ & $3,63 \%$ & & & & & & & & & & & & & & \\
\hline & & KOMULATIF NILAI HASIL & & - & $4.61 \%$ & $9.77 \%$ & $12.79 \%$ & $18.72 \%$ & $25.04 \%$ & $30.76 \%$ & $34.62 \%$ & $40,73 \%$ & $44,36 \%$ & & & & & & & & & & & & & & \\
\hline
\end{tabular}

Gambar 1. Kurva S proyek 


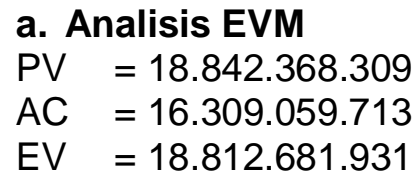

\section{Kinerja Biaya}

Cost variance $(\mathrm{CV})$

$=\mathrm{EV}-\mathrm{AC}$

$=18.812 .681 .931-16.309 .059 .713$

$=2.506 .378 .499$

$C V(\%)=\frac{\square \square}{\square \square}=\frac{2 \cdot 506 \cdot 378 \cdot 499}{16 \cdot 309 \cdot 059 \cdot 713}=13,32 \%$

Cost Performance Index (CPI)

$=\frac{\square \square}{\square \square}=\frac{18.812 \cdot 681.931}{16.309 .059 .713}$

$=1,153706112$

\section{Kinerja Jadwal}

Schedule Variance (SV)

$=\mathrm{EV}-\mathrm{PV}$

$=18.812 .681 .931-18.842 .368 .309$

$=-29.686 .378$

$\operatorname{SV}(\%)=\frac{\square \square}{\square \square}=\frac{-29 \cdot 686 \cdot 378}{16 \cdot 309 \cdot 059 \cdot 713}=-0,16 \%$

Schedule Performance Index (SPI)

$=\frac{\square \square}{\square \square}=\frac{18 \cdot 812 \cdot 681 \cdot 931}{18 \cdot 842 \cdot 368 \cdot 309}=0,998424488$

Indeks Kinerja Biaya dan Jadwal

Schedule Cost Index $(\mathrm{SCl})=$ Critical Ratio $(\mathrm{CR})$

$=\mathrm{CPI}{ }^{*} \mathrm{SPI}$

$=1,153706112 * 0,998424488$

$=1,15$

\section{Peramalan Proyek (Project forcasting)}

Indeks Kinerja Penyelesaian Proyek

$\mathrm{TCPI}=\frac{(\square \square \square-\square \square)}{(\square \square \square-\square \square)}$

$=\frac{(42 \cdot 409 \cdot 111 \cdot 657-18 \cdot 812 \cdot 681 \cdot 931)}{(42 \cdot 409 \cdot 111 \cdot 657-16 \cdot 309 \cdot 059 \cdot 713)}=0,90$

$\mathrm{ETC}=\frac{(\square \square \square-\square \square)}{(\square \square}$

$=\frac{(42.409 .111 .657-18.812 .681 .931)}{1,153706112}$

$=20.452 .721 .437$

$\mathrm{IEAC}=\mathrm{AC}+\mathrm{ETC}$

$=16 \cdot 309.059 .713+20.452 \cdot 721.437$
$=36.759 .024 .869$

$\mathrm{VAC}=\mathrm{BAC}-\mathrm{IEAC}$

$=42.409 .111 .657-36.759 .024 .869$

$=5.650 .086 .788$

$\operatorname{VAC}(\%)=\mathrm{VAC} / \mathrm{BAC}$

$=5.650 .086 .788 / 42.409 .111 .657$

$=13,32 \%$

$\mathrm{IEAC}_{(\mathrm{t})}=(\mathrm{BAC} / \mathrm{SPI}) /(\mathrm{BAC} /$ bulan $)$

$=\frac{(42 \cdot 409 \cdot 111 \cdot 657 / 0,998424488)}{(42 \cdot 409 \cdot 111 \cdot 657 / 5)}$

$=5,007889991$ bulan

\section{b. Analisis ES}

Kinerja Jadwal

Schedule Variance

$(\mathrm{SVt})=\mathrm{ES}-\mathrm{AT}$

AT $=9$ minggu

$\mathrm{ES}=\mathrm{C}+\mathrm{I}$

$\mathrm{PV}($ minggu ke-8) $=17.366 .531 .224$

$\mathrm{EV}($ minggu ke-9) $=18.812 .681 .931$

$\mathrm{PV}($ minggu ke-9) $=18.842 .368 .309$

Karena

$\mathrm{PV}(\mathrm{ke}-8)<\mathrm{EV}(\mathrm{ke}-9)<\mathrm{PV}(\mathrm{ke}-9)$, dengan cara interpolasi maka diperoleh nilai $\mathrm{C}=8,93$ $P V c=17.367 .606 .923$

$$
\begin{aligned}
I & =\left(E V-P V_{c}\right) /\left(P V_{c+1}-P V_{c}\right) \\
& =\frac{(18.812 \cdot 681 \cdot 931-17 \cdot 367.606 .923)}{(0-17 \cdot 367.606 .923)}=0,52
\end{aligned}
$$

Sehingga $E S=8,98+0,52$

$$
\begin{aligned}
\mathrm{ES}= & 9,44 \\
\mathrm{SVt} & =9,44-9 \\
& =0,44 \text { minggu } \\
\mathrm{SPI}_{(\mathrm{t})} & =\mathrm{ES} / \mathrm{AT} \\
& =9,44 / 9=1,04 \\
\mathrm{SCl}_{(\mathrm{t})} & =\mathrm{SPI}(\mathrm{t}){ }^{*} \mathrm{CPI} \\
& =1,04{ }^{*} 1,15 \\
& =1,026
\end{aligned}
$$

Peramalan Proyek (Project forcasting)

Indeks kinerja penyelesaian terhadap waktu $\mathrm{TSPI}_{(\mathrm{t})}=(\mathrm{PD}-\mathrm{ES}) /(\mathrm{PD}-\mathrm{AT})$

$$
\begin{aligned}
& =(21-9,44) /(21-9) \\
& =0,963
\end{aligned}
$$




$$
\begin{aligned}
\operatorname{IEAC}_{(\mathrm{t})} & =\mathrm{AT}+(\mathrm{PD}-\mathrm{ES}) / \mathrm{PF}_{(\mathrm{t})} \\
& =9+(21-9,44) / 1,04 \\
& =20,115 \text { minggu } \\
\text { ETC }_{(\mathrm{t})} & =\mathrm{IEAC}_{(\mathrm{t})}-\mathrm{AT} \\
& =20,115-9=11,115 \text { minggu }
\end{aligned}
$$

Pada metode EVM, ada beberapa parameter yang telah diketahui dari data proyek antara lain anggaran yang direncanakan (PV), dan biaya aktual (AC). Melalui dua parameter ini kemudian dapat dihitung besarnya nilai hasil yang diperoleh (EV). Nilai hasil ini kemudian diinterpretasikan terhadap variabel biaya dan variabel waktu melalui nilai varians yaitu CV dan SV maupun melalui indeks yaitu CPI dan SPI. Nilai-nilai varian diperoleh dengan jalan mencari selisih nilai antara nilai hasil (EV) dengan nilai anggaran rencana (PV) untuk mendapatkan varian waktu (SV) dan mencari selisih antara nilai hasil (EV) dengan nilai biaya aktual untuk mendapatkan varian biaya (CV). Sedangkan nilai-nilai indek didapatkan dengan membagi nilai hasil dengan nilai anggaran rencana untuk mendapatkan indek waktu (SPI) dan membagi dengan nilai biaya aktual untuk mendapatkan indek biaya (CPI).

Secara prosedural, penggunaan metode ES pada prinsipnya adalah hampir sama dengan metode earned value yang sudah digunakan empat puluh tahun lebih sebagai salah satu alat manajemen kinerja proyek. Perbedaan mendasar antara kedua metode ini adalah terletak pada pengukuran kinerja waktu.Konsep earned scheduleyang diperkenalkan pada tahun 2003 oleh Lipke dalam artikelnya yang berjudul "schedule is different" mendemonstrasikan pengukuran kinerja waktu dengan menggunakan unit waktu daripada unit biaya. Beberapa bulan berikutnya pada tahun yang sama sebuah artikel yang dibuat oleh Henderson (2003) yang berjudul "Earned Schedule:A BreakthroughExtension to Earned Value Theory? A Retrospective Analysis of Real Project Data"memverifikasi penggunakan metode ES dan indikator-indikator yang dihasilkannya dapat berfungsi sesuai dengan apa yang diuraikan pada artikel pertama yang dibuat oleh Lipke.Jadi kinerja waktu pada metode earn schedule dijelaskan dalam unit waktu yang lebih mudah dipahami daripada mengukur waktu namun diperoleh dari unit biaya seperti yang dilakukan pada metode EVM.
Perbedaan pengukuran kinerja waktu dan biaya antara metode EVM dan metode ES dapat dilihat pada contoh kasus pada penelitian ini.

Tinjauan dengan menggunakan metode EVM dapat digambarkan dengan grafik pada Gambar 2 dan Gambar 3.

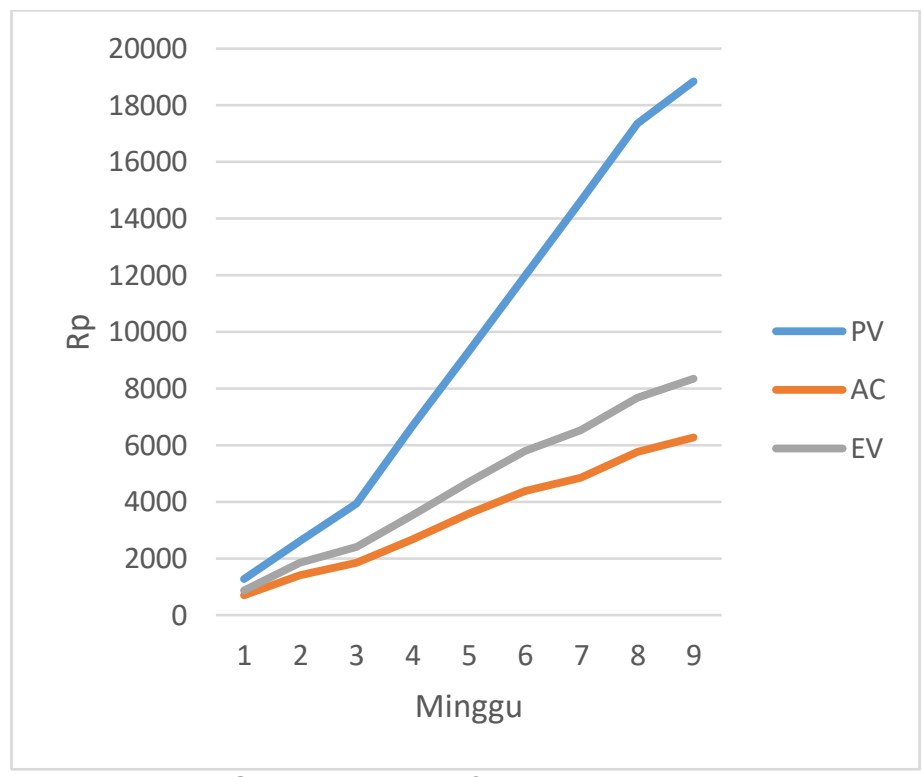

Gambar 2. PV, AC, dan EV

Grafik pada Gambar 2 adalah perbandingan nilai kumulatif PV, AC, dan EV dari minggu ke-1 sampai minggu ke-9 yang dibuat berdasarkan data-data pada Gambar 1.

Berdasarkan grafik pada Gambar 2, jelas terlihat bahwa kinerja proyek adalah mengalami keterlambatan daripada waktu yang telah direncanakan. Namun demikian, apabila dilihat dari aspek penggunaan biaya maka biaya yang dikeluarkan adalah masih lebih kecil atau dibawah dari biaya yang dianggarkan. 


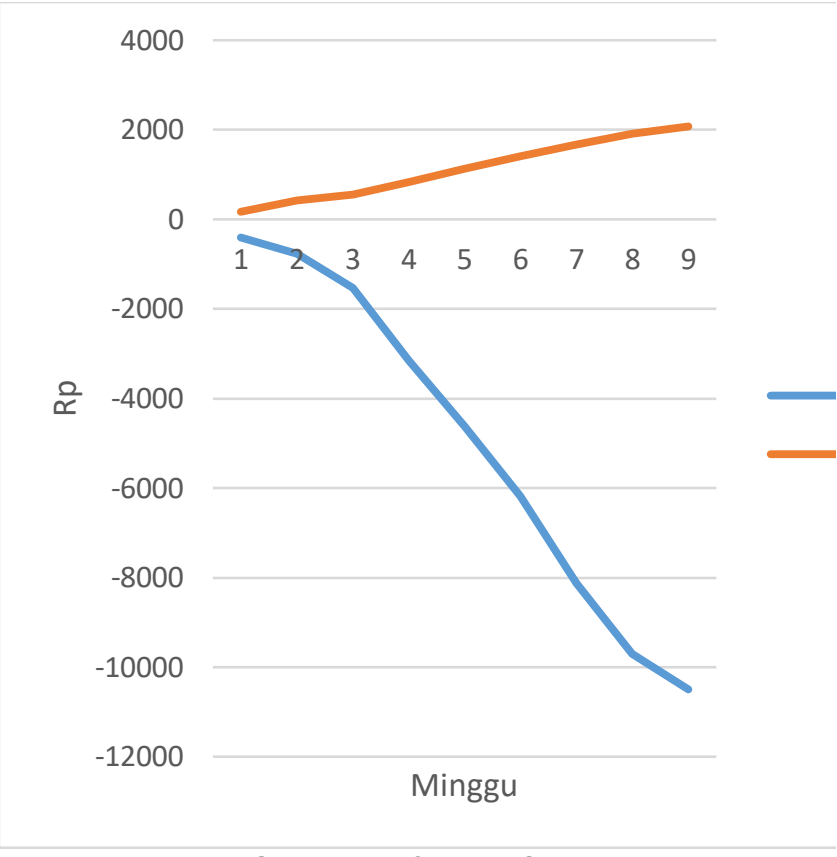

Gambar 3. CV dan SV

Berdasarkan Gambar 3, terlihat bahwa nilai CV (varian biaya) dari minggu ke 1 sampai dengan minggu ke-9 berada di atas sumbu $X$ (bernilai positif). Kondisi grafik CV sesuai dengan Tabel 1, mengindikasikan adanya penghematan penggunaaan biaya untuk penyelesaian pekerjaan. Namun kondisi ini berbanding terbalik dengan kinerja waktu, Gambar 3 menggambarkan bahwa nilai SV dari minggu ke-1 sampai dengan minggu ke- 9 berada di bawah sumbu $X$ (bernilai negatif) sehingga sesuai dengan Tabel 1, mengindikasikan adanya keterlambatan pelaksanaan pekerjaan.

Pada Gambar 1, maka minggu ke-9 adalah minggu saat diadakannya evaluasi terhadap kinerja waktu dan biaya. Pada minggu ke-9 ini dapat dicari bahwa nilai varian biaya adalah sebesar 2.506.378.499, apabila dilihat dari nilai prosentase sebesar $13,32 \%$ maka ini berarti bahwa penggunaan budget $13,32 \%$ berada di bawah anggaran yang direncanakan. Hal ini diperkuat dengan Nilai indeks CPI yang sebesar 1,153706112. Nilai indeks ini mengindikasikan bahwa kinerja penggunaan biaya cukup baik dimana setiap rupiah anggaran proyek yang digunakan mampu memberikan nilai lebih sebesar 0, 153706112.

Pada aspek schedule diperoleh varian sebesar -29.686 .378 atau $-0,16 \%$, ini berarti pelaksanaan proyek mengalami keterlambatan sebesar $0,16 \%$ dari jadwal yang direncanakan. Apabila dilihat dari indeks kinerja jadwal (SPI) dimana diperoleh nilai sebesar 0,998424488. Nilai indeks SPI ini dibawah 1, sehingga proyek terindikasi sedikit terlambat dari jadwal yang direncanakan.

Analisis EVM pada proyek ini juga memprediksi bahwa, apabila kinerja proyek sama seperti pada saat monitoring (minggu ke-9), maka pada saat penyelesaian akan diperoleh penggunaan budget yang lebih rendah dari anggaran yaitu sebesar 5.650.086.788. atau lebih rendah sebesar 13,32\% dari Anggaran yang direncanakan. Sedangkan dari aspek jadwal nilai IEAC (t) $_{(\mathrm{l})}$ sebesar 5,007889991 mengindikasikan bahwa proyek meskipun terlambat namun nilai keterlambatanya sangat kecil.

Tinjauan dengan menggunakan metode ES dapat digambarkan dengan grafik pada Gambar 4. Seperti yang sudah diuaraiakan sebelumnya bahwa prosedur untuk melihat kinerja biaya adalah sama dengan langkahlangkah pada metode EVM, sehingga pada metode ES ini dilihat hanya pada kinerja waktu atau kondisi jadwal perencanaan dibandingkan dengan jadwal pelaksanaan.

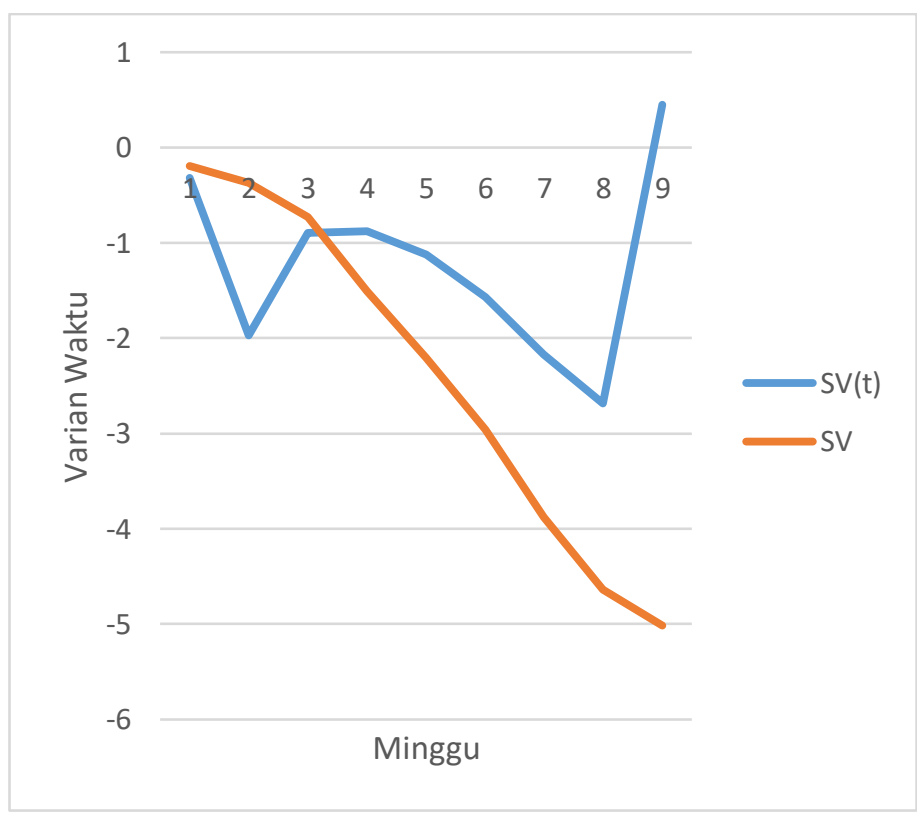

Gambar 4. SV(t) dan SV 


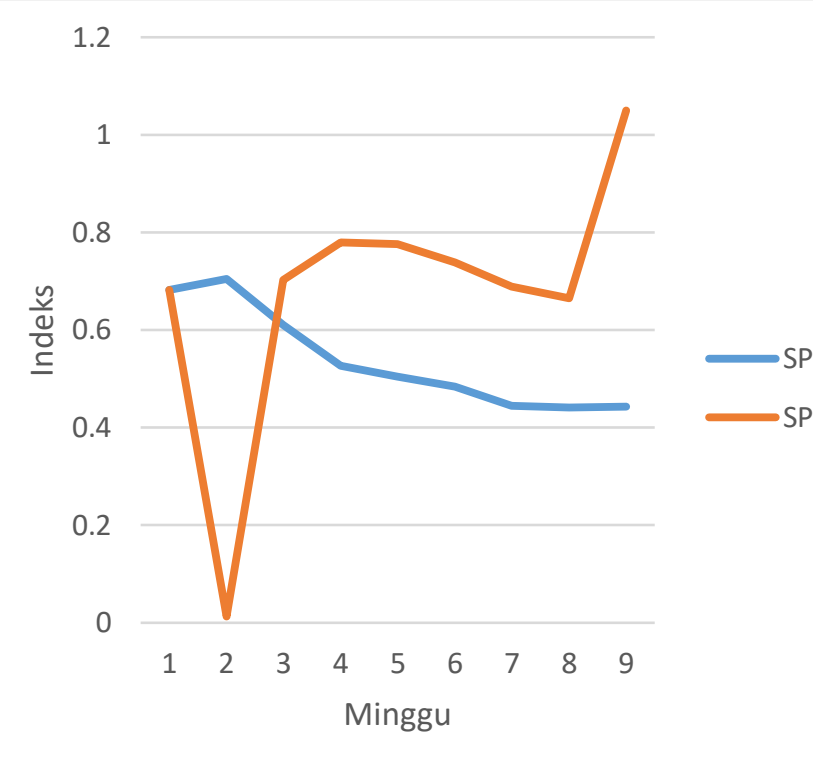

Gambar 5. SPI(t) dan SPI

Berdasarkan Gambar 4 di atas, terlihat bahwa meskipun kedua grafik secara garis besar berada di bawah sumbu X (bernilai negatif), akan tetapi ada perbedaan yang cukup signifikan terhadap hasil perhitungan varian waktu baik itu dari nominal maupun bentuk grafik. SV yang dihasilkan dari metode EVM mengalami peningkatan varian yang sifatnya gradual. Berbeda halnya dengan SV(t) yang dihasilkan dengan menggunkan metode ES, terlihat bahwa ada perubahan varian yang cukup besar terjadi antara minggu ke-2 sampai minggu ke-3 dan minggu ke-8 sampai minggu ke-9. Bahkan pada minggu ke-9 berdasarkan metode ES terlihat bahwa grafik sudah berada di atas sumbu $X$ yang mengindikasikan bahwa waktu pelaksanaan proyek sudah membaik atau lebih cepat dari jadwal yang direncanakan.

Pada analisis dengan metode ES diperoleh nilai SVt adalah sebesar 0,44 minggu, ini berarti terjadi percepatan pelaksanaan proyek sebesar $4,9 \%$ dari jadwal yang seharusnya pada saat monitoring (minggu ke 9).

Keterlambatan ini didukung dengan indeks kinerja jadwal sebesar 1,04. Nilai ini adalah di atas nilai satu yang berarti bahwa kinerja waktu atau jadwal pada minggu ke-9 lebih cepat dari waktu atau jadwal yang direncanakan.

Penyelesaian proyek menurut analisis ES dicapai selama 20,115 minggu dari 21 minggu rencana. Hasil ini menujukkan bahwa kinerja jadwal pada saat monitoring adalah sangat baik sehingga peluang proyek dapat diselesaikan sesuai dengan waktu yang direncanakan adalah sangat besar dengan catatan bahwa kondisi kinerja saat monitoring dipertahankan sampai akhir penyelesaian proyek.

Dari kasus di atas, maka perbandingan perhitungan kinerja waktu dengan menggunakan dua metode tersebut dapat dipahami bahwa metode ES menggunakan benar-benar menggunakan unit waktu untuk menggambarkan varian waktu, hal ini sedikit berbeda dengan metode EVM yang memperoleh varian waktu dari parameterparameter biaya. Perbedaan ini tentu saja akan berpengaruh pada tingkat akurasi maupun kesederhanaan dalam memahami berapa besar perbedaan antara waktu perencanaan dengan waktu pelaksanaan.

\section{SIMPULAN}

Berdasarkan hasil pembahasan, maka dapat disimpulkan atara lain: 1) Kinerja pelaksanaan proyek dari aspek biaya adalah sangat baik dengan varian $13,32 \%$ dari anggaran yang direncanakan; 2) Dilihat dari aspek jadwal maka dengan metode EVM sampai minggu ke-9 proyek secara konstan mengalami keterlambatan. Sedangkan pada metode ES mengindikasikan bahwa proyek mengalami keterlambatan dari sampai minggu ke-8 namun berhasil mengalami percepatan waktu pada minggu ke-9 dari jadwal yang direncanakan; 3) ada aspek jadwal, analisis dengan metode EVM dapat mengindikasikan apakah proyek akan mengalami keterlambatan atau kemajuan dari jadwal rencana, namun demikian analisis dengan metode EVM tidak dapat memberikan informasi mengenai berapa lama waktu keterlambatan atau kemajuan yang diperoleh seperti yang mampu diberikan oleh analisis dengan metode ES yang dihasilkan dari unit satuan waktu.

\section{DAFTAR RUJUKAN}

Agata Czarnigowska. 2011.Project performance reporting and prediction:Extensions of earned value management. International journal of business and management studies. Vol. 3, no 1, 2011 issn: 13098047 (online) 
APM Body of Knowledge. 2006. Association for Project Management. ISBN 1-903494-133.

Angelo Valle, Jose \& Soares, Carlos \& Soares, Pereira. (2004). The Use Of Earned Value Analysis (Eva) In The Cost Management Of Construction Projects.

Czemplik Andrzej. 2014. Application of Earned Value Method to Progress Control of Construction projects. Procedia Engineering 91 (2014) 424-428

Government Accountability Office (GAO). 2012. Earned value management implementation across major spaceflight projects is uneven. Washington, $D C$.

Hecht. Winter 2007-2008. A Case Study of Earned Schedule to do Predictions. TheMeasurable News

Julia Vilella Rojo. 2014. From Earned Schedule Management to Dynamic Scheduling. Université de technologie Belfort-Montbe https://upcommons.upc.edu/bitstream/han dle/2099.1/24034/Final\%20Project\%20Jul ia\%20Vilella\%20Rojo.pdf

Kym Henderson. 2004. Further developments in earnedschedule.

〈http://www.earnedschedule.com/Docs/Fu rther\%20Developments\%20in\%20Earned \%20Schedule.pdf

Kym Henderson. 2007. Earned Schedule: A Breakthrough Extension to Earned Value Management. PMI Asia Pacific Global Congress Proceedings - Hong Kong

Moselhi, Osama. 2011. The Use of Earned Value In Forcasting Project Durations. Proceedings of the 28th ISARC, Seoul, Pages 689-693

PMI - Project Management Institute, 2011. Practice Standard For Earned Value Management. Atlanta2nd Ed., Newtown Square, PA.

Prihadi, W. R., \& Pratama, G. N. I. P. Konfigurasi Batang Pada Perancangan Rangka Atap Bambu. INERSIA, 12(2), 173-183.
Mario Vanhoucke and Stephan Vandevoorde. 2006. A comparison of different project duration forecasting methodsusing earned value metrics. International Journal of Project Management 24 (2006) 289-302.

Mario Vanhoucke and Stephan Vandevoorde. 2007. The Measurable News, Winter 2007-2008

Sagar K. Bhosekar, Gayatri Vyas. (2012). Cost Controlling Using Earned Value Analysis in Construction Industries. International Journal of Engineering and Innovative Technology (IJEIT. Volume 1, 324-332)

Vandevoorde, S., Vanhoucke, M. 2006. A comparison of different project duration forecasting methods using earned value metrics.Int. J. Proj. Manage., 24(4), 289302.

Vanhoucke, M., Vandevoorde, S. 2007. A simulation and evaluation of earned value metrics to forecast the project duration. J. Oper. Res. Soc. 58, 1361-1374.

Walt Lipke. 2003. Schedule is different. 〈http://earnedschedule.com/Docs/Schedul e\%20is\%20Different.pdf $\rangle$

WaltLipke. 2006. Stastical Methods Applied to EVM ... the Next Frontier. The Measurable News ES.

WaltLipke. 2012. Earned ScheduleContribution to Project Management.PM World JournalVol. I, Issue II. www.pmworldjournal.net

Walt Lipke. 2014. Introduction To Earned Schedule. PM World Journal, Vol. III, Issue XI - November. www.pmworldjournal.net.

Wayne J. Del Pico. Project Control: Integrating cost and schedule in construction. John Wiley and Sons: Hoboken 